\title{
COMMUNITY PARTICIPATION AND SUSTAINABILITY OF WATER FLOW PROJECT IN RWANDA: A CASE OF WATER AND SANITATION CORPORATION IN BUGESERA DISTRICT
}

\author{
Monique KANTENGWA ${ }^{1}$, Mercyline KAMANDE ${ }^{2}$, \\ ${ }^{*}$ School of Business and Economics, Business Administration (MBA), Project Management, Mount Kenya University, \\ Kigali, Rwanda \\ ${ }^{2}$ Mount Kenya University
}

*Corresponding Author: -

\begin{abstract}
: -
The communities don't get the opportunity of fully participating in their projects which is at the core cause of the failure and unsustainability of the most of the project conducted among communities. Thus, the researcher conducted a study to evaluate the role of community participation in sustainability of water flow project in Bugesera of Rwanda. This study used descriptive research design to collect data from 268 respondents as the primary informants. The data collected were analyzed by the use of SPSS version 21.0 to produce descriptive statistics with mean and standard deviation and inferential statistics with Pearson correlation and regression analysis based on regression model which is $Y=\beta 0+\beta 1 X 1+\beta 2 X 2+\beta 3 X 3+\varepsilon$, whereby $\beta 0$ is constant of coefficient of determination, whereas $\beta 1, \beta 2$ and $\beta 3$ are coefficients of determination to $X 1, X 2$ and X3 as predictors of community participation. The findings of the study have revealed that there is a relationship between community participation and water flow project as proven by relationship between joint consultation and stakeholder ownership $(r=0.860$ and sig=0.00), between joint consultation and effective management $(r=0.806$ and sig=0.00), between community empowerment and stakeholder satisfaction $(r=0.867$ and sig $=0.00)$ basing on the calculated p-values which are strong and positive and the calculated level of significance which is under

0.01 hence results indicate a positive and significant relationship between community participation and water flow project sustainability in WASAC in Bugesera District. The regression analysis results have shown the positive regression coefficients while the calculate significance level is under 0.05 level of significance implying that the relationship between community participation and stakeholder ownership is positive and significant. Hence, basing on the research findings, the researcher would like to recommend to the management to formulate policies that favor water flow project. Therefore, the researcher would like to recommend to the government to empower its communities and the community members so that the water flow project would be more sustainable. In conclusion, the findings of the study have proven a positively significant relationship between community participation and water flow project sustainability in Bugesera District, Rwanda.
\end{abstract}

Keywords: - Community participation, Sustainability, Water flow project, WASAC, and Rwanda

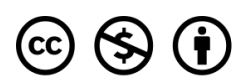

Distributed under Creative Commons CC BY-NC 4.0 OPEN ACCESS 


\section{INTRODUCTION}

For a long time, development assistance projects by the government and non-government agencies have a longlasting history in implementing water project in rural communities to ensure access to safe water which are known to face failure due to poor management and unsustainability of project (Gatari, Mbabazi \& Shukla, 2016). Therefore, it is for this reason the Republic of Rwanda has taken sustainability of water supply projects as the primary priority of National Development Agenda (MININFRA, 2016).

Recently studies conducted in related fields of community participation and project sustainability such as Bal, et al., (2013) and Ndegwa (2015) revealed that there has been an increase of project success and sustainability due to joint consultation and community participation. Both studies conclude that stakeholder and participation of community make contributions to the sustainability of the project, even though their description and clarification had been insufficient in discovering how the involvement of stakeholders in community projects contributes to sustainability. Other researches done by Mukundane (2011); and Chizimba (2013) postulated that the community participation contributes to bringing up sustainability of project if community participates in all project life cycle not only during design and also in implementation, monitoring and controlling the project.

The 2016 WASAC annual report on the overall performance have shown that the accessibility to water in Rwanda stood at $54.0 \%$, with huge disparities between geographical areas where the Eastern Province of Rwanda stood at $36.0 \%$ of safe water accessibility, compared to $74.0 \%$ of safe water accessibility in Kigali and the lowest accessibility of safe water which stood at $24.0 \%$ in the District of Bugesera (WASAC, 2016). However, in the district of Bugesera there are massive disparities with a low level of access to safe water that needs solutions.

Despite, the existence of community participation in sustainability of projects that aims at addressing the problems of water project sustainability, there no much empirical literatures on community participation and project sustainability in Bugesera. Thus, since the previous studies related to community participation and project sustainability has given less attention the sustainability of water flow project in terms of effective management, stakeholder satisfaction and ownership of the project, that is why the researcher conducted this study to raise this concern by assessing the role of community participation in promoting sustainability of water flow project in Bugesera District.

\subsection{Objectives of the study \\ 1.1.1 General objective}

The general objective of the study is to determine the role of community participation in the sustainability of water flow project in Rwanda with a case of WASAC Bugesera Branch.

\subsubsection{Specific objectives}

(i) To assess the role of joint consultation to water flow project sustainability in Bugesera District;

(ii) To examine the role of capacity building on water flow project sustainability in Bugesera District;

(iii)To establish the relationship between community empowerment and water flow project sustainability.

\section{Review of Literature \\ 2.1 Empirical review}

Research carried out by Katsi (2008), on community participation in getting rid of discrimination and inequality in water and sanitation applications in the Zambezi Valley, showed that there used to be once complete failure because local people did not regard the facilities. They noticed such projects as originated from outside. Further research revealed that there was once previously less community involvement shortly earlier than the facility was established; people have left the influence that they do not belong to the characteristic management of the project. This lack of ownership modified the services to look like open entry to a beneficial useful resource (Harvey \& Reed, 2007).

In addition, communities had been separated by the technological information used. It was once not regarded as a village level in terms of operation and maintenance in most applications (Mwakila, 2008). In a report on how carried out to affirm the influence community participation on average performance of water project. Thus, the low level of participation was tested through the identification of project activities, planning of future project activities and implementation and execution of the activities as well as monitoring of them as the phases of the project management. All of these tactics are negatively influenced by project performance (Mukunga, 2012).

Regarding stakeholder ownership, a research conducted by Pomeroy and Oracion (2005) showed that many projects fail to provide sustainable benefits due to lack of huge self-control by stakeholders. The members of the community do not show interest, ownership or commitment. However, when the capacity of the community is well built the project is kept sustainable. Thus, genuine community participation is not an indispensable agenda for applications that are not transparent. Pomeroy and Oracion (2005), stated that ensure that the project is sustainable project stakeholders should make sure that time and resources are investment and are regarded as inexpensive input to enhance tangible outcome; ensure that the design consists of great activities in the implementation of participatory strategies; clearly outlining roles and obligations, and who is predicted to get advantages from them; defining the degree and the type of participation to be carried out and, at the end, make sure that the community is enough and capable in participatory strategies.

The study of Mukunga (2012) stated that communities are charged fees for water even though a lot of water sinks 
due to negligence. Another problem that affected people's willingness to fully participate in administration and sustainability of water flow projects is the fear of being exploited by neighborhood leaders, who are usually at the forefront of regional benefits. The study also proved that resources raised from community water projects are misused and since they are small profits made honestly from the projects are not used properly to be gained by the community rather those profits grew up to benefit the leaders and gain better life from the community water projects, and this hinders the sustainability of the project.

Sara and Katz (2007) conducted research in examining the responsiveness of project planning that affect sustainability of the project. Thus, the survey was conducted amongst one hundred and twenty-five communities in ten rural water factories in six countries. Accumulated data directly through observation method and inspection to the project, focus group discussion, and home interviews were also conducted. The hypothesis noted that at the level of community, demand-sensitive water subsidy offerings are more sustainable than these with an awful lot of limited demand response (Sara \& Katz, 2007). The results have shown that the response to demand, which is also related to the choice of community, is positively related to the sustainability of the business. Although the research covered 10 projects from six special countries, the same data collection instrument such as focus group discussion, interview guide and household questionnaire that were filled and gave comparable results in a range of 10 local water projects in a county.

Community participation is by no means homogeneous. There a number of problems that happens due to conflict of interest between social group where it goes to participatory approach due to both cultural and political constraints (Mwakila, 2008). In addition, Mwakila (2008) counseled that a lot of massive participation in decision-making prevents the ongoing project to keep truck on development growth. The results have indicated that participatory planning delays decision-making process through the experience that helps to participate in the scope of the project and supply of the needed expressed distinction of the priorities already set with the aid of the capability of depended on authorities.

\subsection{Research Gap}

A wide variety of researches carried out on community participation on water flow project sustainability appears to have been given less attention and the need to be resolved to tackle many problems and worries related to community participation and project sustainability. Research carried out by Katsi (2008) has targeted entirely on community participation and water and sanitation programs. Therefore, this implies that even if he wanted to look at community participation which is associated with community involvement. He omitted his function in the sustainability of the project. Pomeroy and Oracion (2005) carried out a study on the same field, but only targeted on stakeholder participation and engagement as factors that can also impact genuine community participation.

The previous empirical researches have not taken into account community participation on water flow project sustainability. For instance, the empirical literature of Mukunga (2012) portrayed the role of community participation in increasing community empowerment in terms of training that solves all attitudinal issues and eliminates misunderstandings that hinder sustainability. It seems that even if these investigations have left out some gaps for further research such as this one about community participation and water flow project sustainability, they all support ideas superbly to grant assurance that the sustainability of a project is accomplished through community participation

\section{Materials and Methods}

The researcher used the descriptive research design to collect the information using the quantitative and qualitative approaches that enabled the researcher to have the descriptive statistics which measured the central tendency of the results and the inferential statistics that made her to make decisions and prove the existence of relationship between community empowerment of project sustainability through use of correlation and regression analysis. The 268 respondents were selected as a sample of this research by applying the simple random and simple random sampling techniques. This sample is drawn from 638 people using Krejcie and Morgan Table that is applied to 596 beneficiaries to give 226 respondents who were selected using a simple random sampling technique with precision level 0.05 with confidence level of 95 percent. The researcher also used simple random to select 42 respondents to increase the number of respondents to the 268 respondents.

The researcher distributed 258 questionnaires to the respondents who are the 226 beneficiaries of the project, 6 local leaders and 24 employees of WASAC to provide the information to the researcher. The questionnaires were self - administered by the researcher where the researcher made sure that there is no information loss to the delay or loss of questionnaire. The researcher has also conducted the interviews to the team of 10 respondents who are in charge of the water flow project in Bugesera. The interviews were conducted personally in order to make sure that the relevant information are captured. The collected data were thematically analyzed into the narratives that correspond to the information provided in quantitative data.

Analysis and processing of data involved gathering information from the field, writing and editing, coding and cleaning and then enter them in SPSS version 21.0 to analyze and produce statistics that consisted of tables of descriptive statistics, tables of regression and correlation tables showing correlation between community participation and project sustainability. The data were analyzed through descriptive and inferential statistics whereby the descriptive statistics used mean, standard deviation, frequency and percentage while the inferential used both Pearson correlation and multiple linear regression analysis. 
The regression analysis was based on regression model which is $\mathrm{Y}=\beta 0+\beta 1 \mathrm{X} 1+\beta 2 \mathrm{X} 2+\beta 3 \mathrm{X} 3+\varepsilon$, whereby $\beta 0$ is constant of coefficient of determination, whereas $\beta 1, \beta 2$ and $\beta 3$ are coefficients of determination to X1, X2 and $\mathrm{X} 3$ as predictors of community participation which are joint consultation, building of capacity and community empowerment and the regression coefficient. Correlation analysis associated the predictors of community participation against the measures of project sustainability which are stakeholder ownership, Effective management on water, and stakeholder satisfaction.

The qualitative data collected using the interview guide was recorded in direct speech of the interviewed after cleansing them as an analysis procedure to avoid including the information that might be in different directions to the academic objective of the study. Thus, the investigator included narrative from respondents in relation to community participation and project sustainability.

\section{Research Findings and Discussion}

4.1 Contribution in joint consultation and water flow project sustainability in Bugesera District

Table 4. 1: Role of joint consultation in water flow project sustainability in Bugesera District, Rwanda

\begin{tabular}{llllllll}
\hline Statements & 5 & 4 & 3 & 2 & 1 & Mean & Std. \\
\hline $\begin{array}{l}\text { I was involve in project design } \\
\text { consultative meeting }\end{array}$ & $8(3.0 \%)$ & $24(9.0 \%)$ & $21(7.8 \%)$ & $54(20.1 \%)$ & $161(60.1 \%)$ & 1.746 & 1.116 \\
$\begin{array}{l}\text { I was involve in needs identification } \\
\text { for this project }\end{array}$ & $8(3.0 \%)$ & $25(9.3 \%)$ & $21(7.8 \%)$ & $44(16.4 \%)$ & $170(63.4 \%)$ & 1.720 & 1.131 \\
$\begin{array}{l}\text { I participated in project financing } \\
\text { consultative meeting }\end{array}$ & $20(7.5 \%)$ & $27(10.1 \%)$ & $17(6.3 \%)$ & $55(20.5 \%)$ & $149(55.6 \%)$ & 1.932 & 1.302 \\
$\begin{array}{l}\text { I support the progress of the project } \\
\text { and work for its sustainability } 20(7.5 \%)\end{array}$ & $23(8.6 \%)$ & $39(14.6 \%)$ & $47(17.5 \%)$ & $139(51.9 \%)$ & 2.022 & 1.298 \\
$\begin{array}{l}\text { I was involved in budget design } \\
\text { consultative discussion for this project }\end{array}$ & $8(3.0 \%)$ & $15(5.6 \%)$ & $23(8.6 \%)$ & $56(20.9 \%)$ & $166(61.9 \%)$ & 1.667 & 1.044 \\
$\begin{array}{l}\text { I am actively engaged in all } \\
\text { development activities of the project }\end{array}$ & $8(3.0 \%)$ & $23(8.6 \%)$ & $33(12.3 \%)$ & $34(12.7 \%)$ & $170(63.4 \%)$ & 1.750 & 1.145 \\
$\begin{array}{l}\text { I am satisfied with my consultative } \\
\text { participation for project sustainability }\end{array}$ & $8(3.0 \%)$ & $23(8.6 \%)$ & $27(10.1 \%)$ & $34(12.7 \%)$ & $176(65.7 \%)$ & 1.705 & 1.134 \\
$\begin{array}{l}\text { I share and receive information } \\
\text { regarding sustainability of the project }\end{array}$ & $8(3.0 \%)$ & $22(8.2 \%)$ & $35(13.1 \%)$ & $107(39.9 \%)$ & $96(35.8 \%)$ & 2.026 & 1.043 \\
$\begin{array}{l}\text { Total mean } \\
\text { Pat }\end{array}$ & & & & & 1.821
\end{tabular}

Source: Primary Data, 2021

The Table 4.1 indicates the Likert scale data are presented by 5 representing not sure, 4 representing to small extent, 3 representing to a moderate extent, 2 representing to a great extent and 1 representing to a very great extent. The mean of 1.705 and standard deviation of 1.134 with $176(65.7 \%)$ of respondents asserted that they are satisfied with consultative participation for project sustainability to a very great extent. The mean of 1.720 and standard deviation of 1.131 with 170 (63.4\%) of respondents asserted that they were involved in needs identification for this project to a very great extent. The mean of 1.750 and standard deviation of 1.145 with $170(63.4 \%)$ of respondents asserted that they actively engaged in all development activities of the project to a very great extent. The mean of 1.667 and standard deviation of 1.044 with $166(61.9 \%)$ of respondents as serted that they were involved in budget design consultative discussion for this project to a very great extent.

The mean of 1.746 and standard deviation of 1.116 with 161(60.1\%) of respondents asserted that they were involved in project design consultative meeting to a very great extent. The mean of 1.932 and standard deviation of 1.302 with $149(55.6 \%)$ of respondents asserted that they participated in project financing consultative meeting to a very great extent. The mean of 2.022 and standard deviation of 1.298 with $139(51.9 \%)$ of respondents asserted that they support the progress of the project and work for its sustainability to a very great extent. The mean of 2.026 and standard deviation of 1.043 with $96(35.8 \%)$ of respondents asserted that they share and receive information regarding sustainability of the project to a very great extent. Since, the total mean of 1.821 shows a great tendency towards very great extent that implies that joint consultation plays role in water flow project sustainability in Bugesera District, Rwanda.

In an interview with one of the team supervisors of water flow project, she has asserted that before starting water flow project a team selected by WASAC from head quarter is sent to the community to consult the local people and local leaders to find out whether the project is needed in the community. She asserted in her own word: "I first came here in 2010 as a data collector in regard water and sanitation and later I got appoint with other colleagues of mine to start up this project here in Bugesera basing on the information we had collected. I am sure the information we collected in 2010 are the ones that are helping us to proceed successfully in this project and I am sure it will be sustainable".

The findings of the study proved that joint consultation plays role in water flow project sustainability which is also supported by the findings of Pomeroy and Oracion (2005) who asserted that genuine community participation is built on consultation which is transparent which invest time and resources in the implementation of participatory strategies that allows project sustainability. 
4.2 Effect of capacity building on water flow project sustainability in Bugesera District Table 4. 2: Statements regarding role of capacity building in sustainability of the project

\begin{tabular}{llllllll}
\hline Statements & 5 & 4 & 3 & 2 & 1 & Mean & Std. \\
\hline $\begin{array}{l}\text { I was given training on } \\
\text { activities regarding water flow } \\
\text { project }\end{array}$ & $8(3.0 \%)$ & $34(12.7 \%)$ & $43(16.0 \%)$ & $34(12.7 \%)$ & $149(55.6 \%)$ & 1.947 & 1.222 \\
$\begin{array}{l}\text { I got access to water flow } \\
\text { project }\end{array}$ & $8(3.0 \%)$ & $42(15.7 \%)$ & $66(24.6 \%)$ & $86(32.1 \%)$ & $66(24.6 \%)$ & 2.403 & 1.109 \\
$\begin{array}{l}\text { I was given tools to use in } \\
\text { water flow project }\end{array}$ & $8(3.0 \%)$ & $38(14.2 \%)$ & $25(9.3 \%)$ & $45(16.8 \%)$ & $152(56.7 \%)$ & 1.899 & 1.221 \\
$\begin{array}{l}\text { The project works towards the } \\
\text { development of stakeholders }\end{array}$ & $8(3.0 \%)$ & $28(10.4 \%)$ & $29(10.8 \%)$ & $38(14.2 \%)$ & $165(61.6 \%)$ & 1.791 & 1.171 \\
$\begin{array}{l}\text { Stakeholders contribute } \\
\text { material resource for project }\end{array}$ & $8(3.0 \%)$ & $34(12.7 \%)$ & $38(14.2 \%)$ & $36(13.4 \%)$ & $152(56.7 \%)$ & 1.917 & 1.218 \\
sustainability & & & & & & \\
$\begin{array}{l}\text { Stakeholder contribute capital } \\
\text { resource for the development }\end{array}$ & $8(3.0 \%)$ & $28(10.4 \%)$ & $29(10.8 \%)$ & $30(11.2 \%)$ & $173(64.6 \%)$ & 1.761 & 1.178 \\
of the project & & & & & & \\
$\begin{array}{l}\text { I am willing to give all } \\
\text { required resource for the }\end{array}$ & $8(3.0 \%)$ & $34(12.7 \%)$ & $44(16.4 \%)$ & $34(12.7 \%)$ & $148(55.2 \%)$ & 1.955 & 1.223 \\
sustainability of the project \\
$\begin{array}{l}\text { I only do what is required not } \\
\text { more not less for the project }\end{array}$ & $8(3.0 \%)$ & $39(14.6 \%)$ & $41(15.3 \%)$ & $34(12.7 \%)$ & $146(54.5 \%)$ & 1.988 & 1.246 \\
sustainability & & & & & & & \\
$\begin{array}{l}\text { I attend meeting for project } \\
\text { sensitization and awareness } \\
\text { Total mean }\end{array}$ & $8(3.0 \%)$ & $34(12.7 \%)$ & $40(14.9 \%)$ & $32(11.9 \%)$ & $154(57.5 \%)$ & 1.917 & 1.224 \\
\hline
\end{tabular}

Source: Primary Data, 2021

The Table 4.2 indicates the Likert scale data of 5 scale point where 5 represents not sure, 4 represents to small extent, 3 represents to o a moderate extent, 2 represents to a great extent, 1 represents to a very great extent). The mean of 1.761 and standard deviation of 1.178 with $173(64.6 \%)$ of respondents asserted that stakeholder contribute capital resource for the development of the project to a very great extent. The mean of 1.791 and standard deviation of 1.171 with $165(61.6 \%)$ of respondents asserted that the project works towards the development of stakeholders to a very great extent. The mean of 1.917 and standard deviation of 1.224 with $154(57.5 \%)$ of respondents asserted that they attended meeting for project sensitization and awareness to a very great extent. The mean of 1.899 and standard deviation of 1.221 with 152(56.7\%) of respondents asserted that they were given tools to use in water flow project to a very great extent.

The mean of 1.761 and standard deviation of 1.178 with $152(56.7 \%)$ of respondents asserted that stakeholders contribute material resource for project sustainability to a very great extent. The mean of 1.947 and standard deviation of 1.222 with $149(55.6 \%)$ of respondents asserted that they were given training on activities regarding water flow project to a very great extent. The mean of 1.955 and standard deviation of 1.223 with $148(55.2 \%)$ of respondents asserted that they are willing to give all required resource for the sustainability of the project to a very great extent. The mean of 1.988 and standard deviation of 1.246 with 146(54.5\%) of respondents asserted that they only do what is required not more not less for the project sustainability to a very great extent. The mean of 2.403 and standard deviation of 1.109 with $86(32.1 \%)$ of respondents asserted that they got access to water flow project to a great extent. The total mean of 1.953 shows a strong tendency towards very great extent which implies that capacity building plays a role in sustainability of water flow project in Bugesera District, Rwanda.

In an interview conducted with the manager of the water flow project, he asserted that capacity building is the cornerstone to enhance the sustainability of water flow project. To ensure that both community and staff are empowered the local were trained on the use of water that is provided to them and the way of treating with care the water taps that they are given. The staffs were also given training and their welfare is also made a priority to encourage their work and hence sustainability of water flow project.

The results of the study have indicated that capacity building plays a role in sustainability of water flow project which is supported by the results of the research of Pomeroy and Oracion (2005) who asserted that when the capacity of the community is well built the project is kept sustainable. Their results added that many projects fail to provide sustainable benefits due to lack of huge self-control by stakeholders. 
4.3 Relationship between community empowerment and water flow project sustainability in Bugesera District, Rwanda

Table 4.3: Statements regarding community empowerment and water flow project sustainability in Bugesera District, Rwanda

\begin{tabular}{llllllll}
\hline Statements & $\mathbf{5}$ & $\mathbf{4}$ & $\mathbf{3}$ & $\mathbf{2}$ & $\mathbf{1}$ & Mean & Std. \\
\hline $\begin{array}{l}\text { I participate in project } \\
\text { meetings }\end{array}$ discouraging \\
inequality in water and \\
sanitation
\end{tabular}

\section{Source: Research Data, 2021}

The Table 4.3 indicates the Likert scale data which are represented 5 points whereby 5 stands for not sure, 4 standards for to small extent, 3 stands for to a moderate extent, 2 stands for to a great extent, and 1 stands for to a very great extent. The mean of 1.761 and standard deviation of 1.178 with $173(64.6 \%)$ of respondents asserted that they participated in monitoring and evaluation of project activities to a very great extent. The mean of 1.917 and standard deviation of 1.224 with $154(57.5 \%)$ of respondents asserted that they participated in mobilization of project resources to a very great extent. The mean of 1.917 and standard deviation of 1.218 with $152(56.7 \%)$ of respondents asserted that they participated in operation and maintenance activities of the project to a very great extent. The mean of 1.917 and standard deviation of 1.218 with $152(56.7 \%)$ of respondents asserted that community empowerment promotes project sustainability to a very great extent.

The mean of 1.955 and standard deviation of 1.223 with $148(55.2 \%)$ of respondents asserted that they participate in planning project activities to a very great extent. The mean of 2.003 and standard deviation of

1.258 with $146(54.5 \%)$ of respondents asserted that they participated in project meetings discouraging inequality in water and sanitation to a very great extent. The mean of 1.988 and standard deviation of 1.246 with 146 (54.5\%) of respondents asserted that they participated in creating sustainable benefits for the project to a very great extent. The mean of 2.003 and standard deviation of 1.258 with $146(54.5 \%)$ of respondents asserted that they participate in responsive planning of the project to a very great extent. The total mean of 1.933 shows that there is a strong tendency to a very great extent which implies that community empowerment affects water flow project sustainability in Bugesera District, Rwanda.

During this study, the researcher managed also to conduct an interview on a local leader in Bugesera. He asserted that despite that the East province including Bugesera is among the areas of Rwanda that has many lakes but Bugesera has a record of the area of lack of water and drought for decades but currently the problem is getting solved though it is not yet. He also said that bring water near the people is another type of community empowerment because the women and children in Bugesera were very well known on riding bicycles for a long distance in the search of water but now the issue is being solved by water flow project. Thus, since the community has interest in the project there is no doubt that the project will keep being sustainable.

The results of the study have shown that community empowerment affect water flow project sustainability as it is supported by the study of Mukunga (2012) who portrayed that the role of community participation in increasing community empowerment in terms of training that solves all attitudinal issues and eliminates misunderstandings that hinder sustainability. 
Table 4. 4: Statements regarding satisfaction on community participation towards sustainability of the project

\begin{tabular}{|c|c|c|c|c|c|c|c|}
\hline Statements & 5 & 4 & 3 & 2 & 1 & Mean & Std. \\
\hline $\begin{array}{l}\text { I feel satisfied with my level } \\
\text { of participation in needs } \\
\text { assessment of the project }\end{array}$ & $8(3.0 \%)$ & $28(10.4 \%)$ & $29(10.8 \%)$ & $30(11.2 \%)$ & $173(64.6 \%)$ & 1.761 & 1.178 \\
\hline $\begin{array}{l}\text { I am satisfied with the } \\
\text { contribution of this project on } \\
\text { community empowerment }\end{array}$ & $8(3.0 \%)$ & $34(12.7 \%)$ & $44(16.4 \%)$ & $34(12.7 \%)$ & $148(55.2 \%)$ & 1.955 & 1.223 \\
\hline $\begin{array}{l}\text { I feel satisfied with how I got } \\
\text { consulted and involved in } \\
\text { this project }\end{array}$ & $8(3.0 \%)$ & $34(12.7 \%)$ & $38(14.2 \%)$ & $36(13.4 \%)$ & $152(56.7 \%)$ & 1.917 & 1.218 \\
\hline $\begin{array}{l}\text { I am satisfied with trainings } \\
\text { of this project in terms of } \\
\text { capacity building }\end{array}$ & $8(3.0 \%)$ & $34(12.7 \%)$ & $38(14.2 \%)$ & $36(13.4 \%)$ & $152(56.7 \%)$ & 1.917 & 1.218 \\
\hline $\begin{array}{l}\text { I am satisfied on how I got } \\
\text { involved in planning for this } \\
\text { project }\end{array}$ & $8(3.0 \%)$ & $28(10.4 \%)$ & $29(10.8 \%)$ & $30(11.2 \%)$ & $173(64.6 \%)$ & 1.761 & 1.178 \\
\hline $\begin{array}{l}\text { I feel satisfied with my } \\
\text { contribution in this project } \\
\text { monitoring and evaluation }\end{array}$ & $8(3.0 \%)$ & $34(12.7 \%)$ & $44(16.4 \%)$ & $34(12.7 \%)$ & $148(55.2 \%)$ & 1.955 & 1.223 \\
\hline $\begin{array}{l}\text { I feel satisfied with } \\
\text { sustainable activities that my } \\
\text { project conducted }\end{array}$ & $8(3.0 \%)$ & $39(14.6 \%)$ & $41(15.3 \%)$ & $34(12.7 \%)$ & $146(54.5 \%)$ & 1.988 & 1.246 \\
\hline $\begin{array}{l}\text { I feel satisfied with my level } \\
\text { of information sharing to } \\
\text { enhance this project } \\
\text { sustainability }\end{array}$ & $8(3.0 \%)$ & $34(12.7 \%)$ & $40(14.9 \%)$ & $32(11.9 \%)$ & $154(57.5 \%)$ & 1.917 & 1.224 \\
\hline Total mean & & & & & & 1.896 & \\
\hline
\end{tabular}

Source: Research Data, 2021

The Table 4.4 indicates Likert scale data of 5 point whereby 5 represents not sure, 4 represents very dissatisfied, 3 represents dissatisfied, 2 represents satisfied, 1 represents very satisfied. The mean of 1.761 and standard deviation of 1.178 with $173(64.6 \%)$ of respondents asserted that they felt satisfied with their level of participation in needs assessment of the project to a very great extent. The mean of 1.761 and standard deviation of 1.178 with $173(64.6 \%)$ of respondents asserted that they am satisfied on how they got involved in planning for this project to a very great extent. The mean of 1.917 and standard deviation of 1.224 with $154(57.5 \%)$ of respondents asserted that they feel satisfied with their level of information sharing to enhance this project sustainability to a very great extent.

The mean of 1.917 and standard deviation of 1.218 with $152(56.7 \%)$ of respondents asserted that they feel satisfied with how they got consulted and involved in this project to a very great extent. The mean of 1.917 and standard deviation of 1.218 with $152(56.7 \%)$ of respondents asserted that they are satisfied with trainings of this project in terms of capacity building to a very great extent. The mean of 1.955 and standard deviation of 1.223 with $148(55.2 \%)$ of respondents asserted that they satisfied with the contribution of this project on community empowerment to a very great extent.

The mean of 1.955 and standard deviation of 1.223 with $148(55.2 \%)$ of respondents asserted that they feel satisfied with their contribution in this project monitoring and evaluation to a very great extent. The mean of 1.988 and standard deviation of 1.246 with $146(54.5 \%)$ of respondents asserted that they feel satisfied with sustainable activities that their project conducted to a very great extent. The total mean is 1.896 with a strong tendency of very satisfied implying that the overall perception can be taken which proves that satisfaction on community participation affect water flow project sustainability in Bugesera District, Rwanda.

The results of the study have proven that satisfaction on community participation affect water flow project sustainability as supported by the research of Katsi (2008) done on community participation in getting rid of discrimination and inequality in water and sanitation applications in the Zambezi Valley. His study supports this study by asserting that community involvement influences sustainable management of water and sanitation project in the Zambezi Valley. 
Table 4.5: Correlation analysis between community participation and water flow project sustainability in Bugesera District, Rwanda

\begin{tabular}{|c|c|c|c|c|}
\hline & & $\begin{array}{l}\text { Stakeholder } \\
\text { ownership }\end{array}$ & $\begin{array}{l}\text { Effective } \\
\text { management }\end{array}$ & $\begin{array}{l}\text { Stakeholder } \\
\text { satisfaction }\end{array}$ \\
\hline \multirow{3}{*}{ Joint consultation } & Pearson Correlation & $.860^{* *}$ & $.806^{* *}$ & $.862^{* *}$ \\
\hline & Sig. (2-tailed) & .000 & .000 & .000 \\
\hline & $\mathrm{N}$ & 268 & 268 & 268 \\
\hline \multirow{3}{*}{ Capacity building } & Pearson Correlation & $.855^{* *}$ & $.804^{* *}$ & $.871^{* *}$ \\
\hline & Sig. (2-tailed) & .000 & .000 & .000 \\
\hline & $\mathrm{N}$ & 268 & 268 & 268 \\
\hline \multirow{3}{*}{$\begin{array}{l}\text { Community } \\
\text { empowerment }\end{array}$} & Pearson Correlation & $.839^{* * *}$ & $.837^{* * *}$ & $.867^{* *}$ \\
\hline & Sig. (2-tailed) & .000 & .000 & .000 \\
\hline & $\mathrm{N}$ & 268 & 268 & 268 \\
\hline
\end{tabular}

Source: Research Data, 2021

The findings in Table 4.5 proves that there is a relationship between joint consultation and stakeholder ownership $(r=0.860$ and $\operatorname{sig}=0.00)$, between joint consultation and effective management $(r=0.806$ and sig=0.00). The results also revealed a positive significant relationship between joint consultation and stakeholder satisfaction $(r=0.862$ and sig=0.00), between capacity building and stakeholder ownership ( $\mathrm{r}=0.855$ and sig=0.00), between capacity building and effective management $(\mathrm{r}=0.804$ and $\mathrm{sig}=0.00)$, between capacity building and stakeholder satisfaction $(r=0.871$ and $\operatorname{sig}=0.00)$.

There is also a positive relationship between community empowerment and stakeholder ownership ( $\mathrm{r}=0.839$ and $\operatorname{sig}=0.00)$ between community empowerment and effective management ( $\mathrm{r}=0.837$ and sig=0.00) between community empowerment and stakeholder satisfaction $(r=0.867$ and sig $=0.00)$ because all calculated $p$ - values are less than 0.01 level of significance. Thus, implies that there is a relationship between predictors of community participation and water flow project sustainability in WASAC in Bugesera Distict.

\section{6: Coefficients of community participation and stakeholder ownership in Bugesera District, Rwanda}

\begin{tabular}{llllll}
\hline Model & \multicolumn{2}{l}{ Unstandardized Coefficients } & Standardized Coefficients & $\mathrm{t}$ & \multirow{2}{*}{ Sig. } \\
\cline { 2 - 4 } & $\mathrm{B}$ & Std. Error & Beta & & \\
\hline (Constant) & .171 & .085 & & 2.014 & .045 \\
Joint consultation & .326 & .063 & .334 & 5.149 & .000 \\
Capacity building & .313 & .063 & .315 & 5.006 & .000 \\
Community & .295 & .056 & .292 & 5.264 & .000 \\
empowerment & & & & \\
\hline
\end{tabular}

a. Dependent Variable: Stakeholder ownership

Source: Research Data, 2021

The Table 4.6 show the positive regression coefficients between community participation predictors and stakeholder ownership of the project of water flow in Bugesera District. This assumption is proved by the regression equation $\mathrm{Y}=\beta 0+\beta 1 \mathrm{X} 1+\beta 2 \mathrm{X} 2+\beta 3 \mathrm{X} 3+\varepsilon$ which turned into $\mathrm{Y}=.171+.326 \mathrm{X} 1+.313 \mathrm{X} 2+.295 \mathrm{X} 3$. Thus, the coefficients between joint consultation and stakeholder ownership $(b=0.326$ and sig=0.00), between capacity building and stakeholder ownership $(\mathrm{b}=0.313$ and $\mathrm{sig}=0.00)$ and between community empowerment and stakeholder ownership $(b=.295$ and sig=0.001). Hence, since the regression coefficients are positive and their corresponding calculated significance values are lesser than (0.05) critical level of significance implies that community participation and stakeholder ownership has a positive and significant relationship in WASAC in Bugesera District.

The findings of the study asserts that there is a positive significant relationship between community participation and stakeholder ownership which is supported by the study of Mukunga (2012) which have revealed that there is a positive relationship between community participation and performance of water project. In his study participation was tested through identification of project activities, planning of future project activities, implementation and execution of the activities as well as monitoring of them as the phases of project management.

Table 4. 7: Coefficients a of community participation and effective management in Bugesera District, Rwanda

\begin{tabular}{|c|c|c|c|c|c|}
\hline \multirow[t]{2}{*}{ Model } & \multicolumn{2}{|c|}{ Unstandardized Coefficients } & \multirow{2}{*}{$\begin{array}{l}\text { Standardized Coefficients } \\
\text { Beta }\end{array}$} & \multirow[t]{2}{*}{$-\mathrm{t}$} & \multirow[t]{2}{*}{ Sig. } \\
\hline & & Std. Error & & & \\
\hline (Constant) & .292 & .095 & & 3.085 & .002 \\
\hline Joint consultation & .193 & .071 & .201 & 2.730 & .007 \\
\hline Capacity building & .221 & .070 & .226 & 3.165 & .002 \\
\hline Community empowerment & .475 & .063 & .477 & 7.590 & .000 \\
\hline
\end{tabular}

Dependent Variable: Effective management

Source: Research Data, 2021 
The Table 4.7 show the positive regression coefficients between community participation predictors and effective management of the project of water flow in Bugesera District. This assumption is proved by the regression equation $\mathrm{Y}=\beta 0+\beta 1 \mathrm{X} 1+\beta 2 \mathrm{X} 2+\beta 3 \mathrm{X} 3+\varepsilon$ which turned into $\mathrm{Y}=0.292+0.193 \mathrm{X} 1+0.221 \mathrm{X} 2+0.475 \mathrm{X} 3$. Thus, the coefficients between joint consultation and effective management $(b=0.193$ and sig=0.007), between capacity building and effective management $(b=0.221$ and $\mathrm{sig}=0.002)$ and between community empowerment and effective management $(b=.475$ and $\operatorname{sig}=0.000)$. Hence, since the regression coefficients are positive and their corresponding calculated significance values are lesser than (0.05) critical level of significance implies that community participation and effective management has a positive and significant relationship in WASAC in Bugesera District.

Table 4. 8: Coefficients a of community empowerment and stakeholder satisfaction in Bugesera District, Rwanda

\begin{tabular}{llllll}
\hline Model & \multicolumn{2}{l}{ Unstandardized Coefficients } & $\begin{array}{l}\text { Standardized } \\
\text { Coefficients }\end{array}$ & t & Sig. \\
\cline { 2 - 5 } & $\mathrm{B}$ & Std. Error & Beta & & \\
\hline (Constant) & .042 & .078 & & .533 & .594 \\
Joint consultation & .232 & .058 & .237 & 3.977 & .000 \\
Capacity building & .345 & .058 & .345 & 5.960 & .000 \\
Community empowerment & .383 & .052 & .377 & 7.412 & .000 \\
\hline
\end{tabular}

Source: Research Data, 2021

Table 4.8 show the positive regression coefficients between community participation predictors and stakeholder satisfaction of the project of water flow in Bugesera District. This assumption is proved by the regression equation $\mathrm{Y}=\beta 0+\beta 1 \mathrm{X} 1+\beta 2 \mathrm{X} 2+\beta 3 \mathrm{X} 3+\varepsilon$ which turned into $\mathrm{Y}=0.042+0.232 \mathrm{X} 1+0.345 \mathrm{X} 2+0.383 \mathrm{X} 3$. Thus, the coefficients between joint consultation and stakeholder satisfaction $(b=0.326$ and sig=0.00), between capacity building and stakeholder satisfaction $(b=0.313$ and sig=0.00) and between community empowerment and stakeholder satisfaction $(b=.295$ and $\operatorname{sig}=0.001)$. Hence, since the regression coefficients are positive and their corresponding calculated significance values are lesser than (0.05) critical level of significance implies that community participation and stakeholder satisfaction has a positive and significant relationship in WASAC in Bugesera District.

\subsection{Conclusion}

In the conclusion, the study findings have proven a positive and significant relationship between community empowerment and sustainability of water flow project. The calculated regression coefficients and significance level which are under 0.05 in multiple regression analysis prove positive and significant relationship between community participation and stakeholders' ownership. This conclusion is supported by the study of Mukunga (2012) which have revealed that there is a positive relationship between community participation and performance of water project.

Another point to consider in this conclusion regards the positive and significant relationship between community participation and effective management which is proven by the results of regression coefficients which are positive and significance levels which are under 0.05 and the same apply to stakeholder satisfaction. Thus, this brings the research to conclude that community participation and water flow project has a positive and significant relationship.

\subsection{Acknowledgement}

First and foremost, we would like to extend my appreciations to almighty God for enabling me to accomplish this research work that requires attention and commitment. We are also appreciative of the contribution of the staff of the WASAC branch in Bugesera District. We also express my deep gratitude to Mount Kenya University Staff and Lecturers for all their tireless efforts to support, and educate and equip us all the student knowledge and skills. Last but not the least; appreciations should be extended to my friends, relatives, colleagues and classmates for their moral and material support given to me while doing my masters' degree in Business Administration at Mount Kenya University.

\section{References}

[1].Bal, M., Bryde, D., Fearon, D. \& Ochieng, E. (2013). Stakeholder engagement achieving sustainability in the construction sector. International Journal of Project Management, 12 (3), 18-20.

[2].Chizimba, M. (2013). The sustainability of donor-funded projects in Malawi. Mediterranean Journal of Social Science, 24 (3), 705-714.

[3].Gatari, S., Mbabazi, M, \& Shukla, J. (2016). Factors influencing the sustainability of water projects in Gahondo: A case of water projects in Muhanga district, Rwanda. European Journal of Business and Social Sciences, 16 (3), 32-41.

[4].Harvey, P. \& Reed, R.A. (2007). Community-managed water Supplies in Africa: sustainable or dispendable?

[5].Community Development Journal, 42 (3). DOI: 10.1093 / cdj / bsl001. 
[6].Katsi, L. (2008). Community participation in rural water supply and sanitation projects, gender roles and realities: A case of Ward 22 in Chipinge district, Manicaland province, Zimbabwe. Unpublished Doctoral Thesis. Chinhoyi University of Technology. Chinhoyi, Zimbabwe.

[7].Krejcie, R.V. \& Morgan, D. W. (1970). Determination of Sample Size for research activities, educational and psychological measurement.

[8].Mukundane, M. (2011). Popular Participation in Rural Development Programmes In Uganda Case Study of the National Agricultural Advisory Services Programme in Mbarara District. An unpublished MSc. Thesis in Public Administration and Management Makerere University, Uganda.

[9].Mukunga, F. M. (2012). Influence of community participation on the performance of water projects.

[10]. Unpublished Master Thesis. University of Nairobi. Kenya.

[11]. Mwakila, W. (2008). An Assessment of Community Participation in Water Supply and Sanitation Services: The Case of Yombo Dovya and Barabara ya Mwinyi, Water Community Projects, Temeke, Tanzania. Unpublished Master's Thesis. Institute for Social Studies, The Hague, Netherlands.

[12]. Ndegwa, A. (2015). Factors influencing the sustainability of KEMRI HIV / AIDS Grants funded projects in Kenya, the University of United Sate International Africa.

[13]. Pomeroy, R. S,. \& Oracion, E. (2005). Perceived community economic factors influencing the sustainability of integrated coastal project management in the Philippines. Journal Ocean \& Cost Management, 48 (3- 6): 360-377. DOI: 10.1016 / j.ocecoaman.2005.04.010.

[14]. Sara, G \& Katz, A. (2007). Community participation in making rural water sustainable. Report on the impact on of project rules. The World Bank, Washington, DC

[15]. Water and Sanitation Corporation, (2016). WASAC Annual report.

[16]. Water and Sanitation Corporation. (WASAC), (2016). Impact: A performance Report of Rwanda's Water and Sanitation Services. Kigali, Rwand 